\title{
RESENHA
}

DOI: http://dx.doi.org/10.1590/So034-759020140411

\section{A ÉTICA E O MERCADO: O QUE ESTÁ EM JOGO?}

\section{O QUE O DINHEIRO NÃO COMPRA: OS LIMITES MORAIS DO MERCADO}

De Michael J. Sandel. Rio de Janeiro: Civilização Brasileira, 2012. 237 p.

Nos dias atuais, poucas coisas não são compráveis. As práticas comerciais pouco ortodoxas e muito polêmicas empregadas pelas instituições públicas e privadas em diversas situações ratificam que se vive na era do triunfalismo do mercado, onde praticamente tudo está à venda. Esse fenômeno surgiu após a Segunda Guerra, fundamentado na crença de que os mercados seriam capazes de se regular e gerir os próprios riscos. A crise de 2008 mostrou que as coisas não são bem assim, porém esperava-se que, dados os seus desdobramentos, novos rumos seriam adotados na maneira como o capitalismo funciona, o que não ocorreu.

Sandel, influente filósofo americano da atualidade e professor do curso Justice, na Universidade de Harvard, e autor de outros livros, como Justiça; o que é fazer a coisa certa, afirma que a ganância não foi a única culpada pela crise, mas também o papel ectópico atualmente desempenhado pelo mercado. Em vez de manter-se adstrito às esferas da transação de bens materiais, o mercado governa crescentemente a vida como um todo. Nesse modelo, as principais consequências nocivas dizem respeito à desigualdade e corrupção no seio da sociedade. No caso da primeira, quanto mais forte for o poder do capital, mais importante será sua falta; em outras palavras, as pessoas pobres terão uma vida mais difícil. Com relação à corrupção, ele aponta que as práticas desenvolvidas por algumas organizações comprometem o conceito de cidadania, ao passo que põem à venda itens que não deveriam, pela perspectiva moral, ser vendidos.

De acordo com o autor, os limites morais do mercado devem ser analisados publicamente, mesmo que as crenças sociais tenham de ser abertas, caso contrário, correse risco de ocorrer maior degradação ou corrompimento de aspectos valiosos da vida. Para ele, de maneira sutil e sem que as pessoas percebessem, a sociedade atual deixou de ter uma economia de mercado para ser uma sociedade de mercado. 
Neste livro, o autor traz uma série de exemplos reais, os mais diversos possíveis, e questiona os limites morais das práticas comerciais. Ele afirma que, para determinados produtos, a ética do mercado deve ser empregada, porém, em outros casos, devem-se repensar as condutas.

No primeiro capítulo, "Furando a fila", Sandel discute a ética das filas. Companhias aéreas e parques de diversão que vendem acessos mais rápidos aos serviços, profissionais que esperam na fila de eventos gratuitos e/ou concorridos no lugar de outras pessoas, municípios que cobram pela utilização de vias expressas em horários concorridos, cambistas que cobram fortunas por eventos e até mesmo médicos de butique disponíveis 24 horas por dia. 0 que há de errado nisso? Segundo Sandel, a proliferação desse tipo de comércio "aumenta as vantagens da afluência e condena os mais pobres a ficarem sempre no fim das filas”, ou seja, a lógica de que quem chega primeiro é atendido primeiro (ética da fila) cede passagem à lógica do "pagou, levou" (ética do mercado). Há argumentos contra e a favor de tais práticas, porém o autor defende que pagar e esperar são duas maneiras diferentes de distribuir os bens. Há outras maneiras de distribuição, portanto cada uma deveria ser tratada com regras específicas e válidas para todos.

O capítulo 2, "Incentivos", questiona práticas de bonificação ou punição financeira para comportamentos desejados ou não. Para o autor, quando esse tipo de incentivo é adotado, há limites morais que não são considerados, e isso pode gerar resultados desastrosos em longo prazo, pois as pessoas, principalmente as mais necessitadas ou com menor capacidade de julgamento, por exemplo, as crianças, serão coagidas a vender o que, em tese, não deveria ser vendido. Além disso, o estímulo monetário, extrínseco, substi- tui a responsabilidade pessoal pelos próprios atos.

No Capítulo 3, "Como o mercado descarta a moral”, Sandel aponta duas objeções ao sistema estabelecido. A primeira versa sobre a desigualdade que as escolhas de mercado podem refletir (equanimidade). A segunda diz respeito à corrupção, ou seja, atitudes e normas sociais prejudicadas ou dissolvidas pelas regras do mercado. Ele ainda comenta a mudança no ponto de vista de alguns economistas a respeito da influência do mercado sobre os bens e práticas sociais por ele governados, bem como na mudança de papel do economista no contexto social. Em outras palavras, parte-se gradualmente da visão em que o mercado não interfere no bem comercializado para uma visão mais realista, em que o mercado altera consideravelmente seu caráter. Tal constatação traz à luz os perigos de se misturarem as normas do mercado em esferas da vida normalmente governadas por regras diferentes.

No capítulo 4, "Mercados na vida e na morte", é exposta a indústria multibilionária de seguros de vida que as empresas fazem para seus funcionários e até mesmo ex-funcionários (muitas vezes sem 0 conhecimento destes). 0 autor questiona a coisificação dos trabalhadores, os quais são tratados como mercadorias a futuro e têm mais valor (para as empresas) mortos do que vivos. Isso porque, sob a ótica fiscal, é mais atraente para as empresas realizar esse tipo de transação, pois, em caso de falecimento do segurado, a empresa receberá o valor acordado na apólice e a família do trabalhador não receberá nada.

0 autor finaliza o livro com o capítulo 5, "Direitos de nome", que faz uma análise sobre as novas práticas econômicas no mundo dos esportes. Primeiramente, comenta a venda de autógrafos. Sobre tal prática, ele elucida que há jo- gadores que, teoricamente, não precisavam vender seus autógrafos, mas, mesmo assim, o fazem. Em contrapartida, há aqueles mais tradicionalistas, que se recusam. Também traz exemplos de comercialização de outros artigos esportivos e explica como ocorrem os procedimentos de "autenticação do material". Na sequência, questiona os investimentos privados no nome dos estádios e eventos específicos dentro de disputas esportivas, alegando que, ao se mudar o nome de um estádio, muda-se um marco cívico relevante.

Com enfoque diferente de sua já citada obra, onde aspectos sobre a justiça são debatidos, os diversos pontos abordados por Sandel neste livro propiciam aos leitores uma profunda reflexão sobre a influência das regras do mercado no cotidiano. Nesse sentido, a obra é muito esclarecedora, porém, em contrapartida, não aborda aspectos mais profundos sobre as causas dos casos analisados. Ao focar diretamente o fenômeno, perderam-se, em parte, a visão do todo e a visão pormenorizada das partes. Assim, as bases do sistema capitalista e o papel de cada agente na sociedade não foram tão esmiuçados como poderiam ter sido. Como exemplo de livros que abordam essas questões, $O$ capitalismo na encruzilhada, de Hart (Bookman, 2006), elaborou de maneira pragmática soluções para problemas do mundo capitalista, e Ethics in practice: managing the moral corporation, de Andrews (Harvard Business Press, 1989), abordou as pressões e dificuldades éticas que os executivos enfrentam ao tomar decisões. Independentemente dessas considerações, a obra é eficaz em estimular o pensamento sobre em quais pressupostos as pessoas fundamentam suas escolhas e qual o papel do cidadão na sociedade brasileira da atualidade, principalmente em ano de eleições. 